\title{
SISTEM INFORMASI AKUNTANSI PENERIMAAN DAN PENGELUARAN KAS BERBASIS WEB (STUDI KASUS: PT. SINAR KAPUAS CEMERLANG)
}

\author{
${ }^{1}$ Lisnawanty, ${ }^{2}$ Bambang Kurniawan \\ Program Studi Sistem Informasi Akuntansi Kampus Kota Pontianak, Fakultas Teknologi Informasi \\ Universitas Bina Sarana Informatika \\ 1 lisnawanty.lsy@bsi.ac.id ; 2 bambangkurniawan2565@gmail.com
}

\begin{abstract}
Abstrak
PT. Sinar Kapuas Cemerlang merupakan suatu perusahaan swasta yang bergerak dibidang manufaktur dan perdagangan spring bed. Pengolahan data pada transaksi kas, piutang, penjualan, dan pembayaran biaya menggunakan nota transaksi yang kemudian disalin dengan memanfaatkan Microsoft Excel. Hal ini tentu berdampak pada lamanya waktu yang dibutuhkan untuk merekapitulasi data tersebut menjadi laporan penerimaan dan pengeluaran kas. Maka dari itu, penelitian ini berfokus pada rancangan sistem informasi akuntansi penerimaan dan pengeluaran kas pada PT. Sinar Kapuas Cemerlang. Metode yang digunakan dalam pengembangan software adalah model waterfall. Level akses pengguna terdiri dari Bagian Keuangan dan Direktur. Bagian Keuangan mengolah data barang, data pelanggan, data akun, data sales, data produksi, data penjualan, data penerimaan piutang dan data biaya. Dan Direktur mengolah data pengguna, mengakses laporan persediaan barang, laporan penjualan, laporan buku besar, laporan penerimaan kas, laporan pengeluaran kas, laporan neraca saldo, laporan laba rugi dan laporan perubahan modal. Sistem informasi akuntansi penerimaan dan pengeluaran kas ini diharapkan dapat meningkatkan performa pengolahan data penerimaan dan pengeluaran kas pada PT. Sinar Kapuas Cemerlang.
\end{abstract}

Kata kunci: penerimaan kas, pengeluaran kas, sistem informasi akuntansi

\begin{abstract}
PT. Sinar Kapuas Cemerlang is a private company engaged in the manufacturing and trading of spring beds. Data processing on cash transactions, accounts receivable, sales, and payment of fees using transaction notes which are then copied using Microsoft Excel. This certainly has an impact on the length of time needed to recapitulate the data into cash receipts and disbursements reports. Therefore, this research focuses on the design of accounting information systems for cash receipts and payments at PT. Sinar Kapuas Cemerlang. The method used in software development is the waterfall model. The user access level consists of the Finance Department and Director. The Finance Department processes goods data, customer data, account data, sales data, production data, sales data, receivables data and cost data. And the Director processes user data, accesses inventory reports, sales reports, general ledger reports, cash receipt reports, cash disbursement reports, balance sheet reports, profit and loss reports and capital changes reports. The accounting information system for cash receipts and disbursements is expected to improve the performance of cash receipts and disbursements data processing at PT. Sinar Kapuas Cemerlang.
\end{abstract}

Keywords: cash receipts, cash disbursements, accounting information systems

\section{PENDAHULUAN}

Kemajuan teknologi informasi dan komputer merupakan salah satu yang paling pesat dibandingkan bidang lainnya. Pertumbuhannya semakin meningkat dari tahun ke tahun, hal ini ditandai dengan penggunaan komputer pada segala aspek, baik itu perusahaan jasa, perdagangan, maupun industri, mulai dari perusahaan skala kecil, besar, hingga multi nasional (Sholikhah, Sairan, \& Syamsiah, 2017).

Penggunaan aplikasi sebagai alat bantu

dalam pengambilan keputusan dan aplikasi tersebut digunakan sebagai bahan untuk memperoleh hasil pencarian dari suatu pokok permasalahan. Diharapkan hasilnya akan memberikan solusi serta mengambil keputusan dengan tepat. Penerapan sistem informasi memberikan fasilitas seperti perolehan informasi yang cepat dan tepat pada saat dibutuhkan. Informasi dirancang untuk keperluan pengolahan data dengan penerapan teknologi komputer sehingga seluruh proses kegiatan dapat dikelola menjadi informasi yang bermanfaat (Firmansyah \& Udi, 2017). 
Sistem informasi yang baik dapat menghasilkan laporan keuangan yang akurat. Laporan keuangan ini bersumber dari penerimaan dan pengeluaran kas yang terjadi selama periode transaksi. Laporan keuangan menyediakan informasi tentang keuangan suatu perusahaan pada suatu periode akuntansi yang dapat digunakan untuk menggambarkan kinerja perusahaan tersebut (Riswan \& Kesuma, 2014).

PT. Sinar Kapuas Cemerlang merupakan suatu perusahaan swasta yang bergerak di bidang manufaktur dan perdagangan spring bed. Setiap transaksi seperti pengolahan data kas, piutang, penjualan, dan pembayaran biaya dicatat ke dalam nota-nota transaksi yang kemudian disalin menggunakan Microsoft Excel (Hak, Slamet, \& Kurniawati, 2014). Berdasarkan hasil observasi, untuk menghasilkan laporan penerimaan dan pengeluaran kas pada PT. Sinar Kapuas Cemerlang memerlukan waktu yang lama (Frieyadie, 2015) (Arizona, 2017), dikarenakan Bagian Keuangan harus merekapitulasi satu per satu transaksi (Primandani \& Widodo, 2012) untuk dijadikan laporan laba \& rugi, laporan perubahan modal, neraca dan neraca lajur. Ketika terjadi keterlambatan dalam penyajian laporan (Amin, 2017) pada PT. Sinar Kapuas Cemerlang, tentu akan berpengaruh pada proses pengambilan keputusan khususnya yang berkaitan dengan masalah keuangan. Selain itu, sering terjadi selisih antara rekapitulasi yang dihasilkan antara sub bagian penjualan dengan laporan penerimaan dan pengeluaran kas yang dikelola oleh Bagian Keuangan pada PT. Sinar Kapuas Cemerlang. Alat yang digunakan untuk menganalisa laporan penerimaan dan pengeluaran kas juga belum mendukung secara maksimal dalam menilai kinerja keuangan walaupun sudah dibantu menggunakan Microsoft Excel dalam perhitungan dan penentuan keputusan.

Berdasarkan permasalahan tersebut, maka perlu adanya implementasi sistem informasi akuntansi yang merupakan sistem yang bertujuan untuk mengumpulkan dan memproses data serta melaporkan informasi yang berkaitan dengan transaksi keuangan (Damayanti \& Hernandez, 2018). Maka dari itu, penelitian ini dilakukan dengan tujuan memberikan solusi terhadap pengelolaan transaksi penerimaan dan pengeluaran kas di PT. Sinar Kapuas Cemerlang, berupa sistem informasi akuntansi penerimaan dan pengeluaran kas pada PT. Sinar Kapuas Cemerlang agar dapat mengelola data-data transaksi yang ada menjadi laporan keuangan dengan cepat dan akurat, baik pada level Bagian Keuangan maupun Direktur.

\section{METODE PENELITIAN}

\section{Jenis Penelitian}

Penelitian ini menggunakan teknik deskriptif, yakni metode yang digunakan untuk meneliti suatu objek, suatu set kondisi, suatu sistem pemikiran, ataupun suatu kelas peristiwa pada masa sekarang (Saifudin \& Ardani, 2017). Metode yang digunakan dalam pengembangan software dalam penelitian ini adalah model waterfall, dengan alasan bahwa metode ini melakukan pendekatan secara sistematis dalam proses pengerjaan sistem. Dengan kata lain metode ini tidak berfokus pada satu tahapan tertentu. Tahapan dalam model waterfall ini mencakup tahap analisa kebutuhan perangkat lunak, desain, pembuatan kode program, dan pengujian.

\section{Waktu dan Tempat Penelitian}

Penelitian dilakukan pada tahun 2018 di PT. Sinar Kapuas Cemerlang.

\section{Target/Subjek Penelitian}

Target penelitian (untuk penelitian kualitatif) dilakukan pada PT. Sinar Kapuas Cemerlang dengan subjek penelitian pengolahan transaksi kas masuk dan kas keluar pada Bagian Keuangan.

\section{Prosedur}

Prosedur penelitian yang digunakan sebagaimana yang telah diuraikan pada bagian Jenis Penelitian mengikuti tahapan model waterfall sebagai berikut.

1. Analisis kebutuhan perangkat lunak

Dalam tahapan ini, analisis kebutuhan berfokus pada kebutuhan sistem informasi akuntansi pengolahan laporan keuangan dimulai dari pengumpulan kas, utang, piutang, pembelian, penjualan, penyusutan dan pembayaran biaya.

2. Desain

Tahapan ini mencakup rancangan basis data, pemodelan rancangan menggunakan Unified Modeling Language (UML), dan rancangan tampilan antar muka.

3. Pembuatan Kode Program

Pengkodean (coding) program menggunakan sublime text sebagai web editor bahasa pemrograman hypertext preprocessor (PHP) berdasarkan logika yang dirancang pada tahapan desain.

4. Pengujian

Tahapan pengujian menentukan apakah sistem atau perangkat lunak yang telah dibuat sudah sesuai dengan kebutuhan pengguna 
atau belum dengan metode black box testing sebagai media pengujian.

\section{Teknik Pengumpulan Data}

Teknik pengumpulan data berfungsi sebagai cara untuk mengumpulkan data dari suatu penelitian (Saifudin \& Ardani, 2017). Teknik pengumpulan data yang digunakan, terdiri dari observasi, wawancara dan studi pustaka. Adapun penjelasan dari teknik pengumpulan data yang digunakan, diuraikan sebagai berikut:

1. Observasi

Penulis melakukan observasi langsung ke PT. Sinar Kapuas Cemerlang Kabupaten Mempawah yang beralamat Wajok Hulu Kabupaten Mempawah, Kalimantan Barat 78351 untuk mengamati secara langsung proses pengolahan laporan keuangan dimulai dari pengolahan data kas, utang, piutang, pembelian, penjualan, penyusutan dan pembayaran biaya dan pembuatan laporan keuangan yang diterapkan.

2. Wawancara

Wawancara merupakan proses tanya jawab langsung dan sistematis dengan Bapak Wildem selaku kepala keuangan pada PT. Sinar Kapuas Cemerlang untuk mendapatkan data-data terkait tentang penyusunan laporan keuangan.

\section{HASIL PENELITIAN DAN PEMBAHASAN}

\section{Analisis Kebutuhan Perangkat Lunak}

Analisa kebutuhan kebutuhan merupakan tahap interaksi intensif antara analis sistem dengan komunitas pemakai sistem (end-user), dimana dalam tahapan ini menjelaskan tentang fungsi-fungsi atau kebutuhan pengguna dan kebutuhan sistem.

\section{A. Kebutuhan Pengguna}

Kebutuhan pengguna dari sistem informasi akuntansi penerimaan dan pengeluaran kas pada PT. Sinar Kapuas Cemerlang Kabupaten Mempawah terdiri dari dua (2) level pengguna, yaitu Bagian Keuangan dan Direktur. Skenario kebutuhan dari kedua level pengguna ini akan dijabarkan pada halaman berikut.

A1 Skenario Kebutuhan Bagian Keuangan

Login; Mengolah data barang; Mengolah data pelanggan; Mengolah data akun; Mengolah data sales; Mengolah data produksi; Mengolah data penjualan; Mengolah data penerimaan piutang; Mengolah data biaya; Logout

A2 Skenario Kebutuhan Bagian Direktur

Login; Mengolah data pengguna; Mengakses laporan persediaan barang; Mengakses laporan penjualan; Mengakses laporan buku besar; Mengakses laporan penerimaan kas; Mengakses laporan pengeluaran kas; Mengakses laporan neraca saldo; Mengakses laporan laba rugi; Mengakses laporan perubahan modal; Logout

B. Kebutuhan Sistem

1) Pengguna harus melakukan login dengan cara mengisi username dan password, apabila berhasil login, maka setiap pengguna dapat mengakses sistem informasi penerimaan dan pengeluaran kas ini sesuai dengan level akses.

2) Pengguna harus melakukan logout setelah selesai menggunakan aplikasi.

3) Data buku besar dapat diakses atau dicari berdasarkan nama akun, nama bulan dan tahun.

4) Laporan dapat diakses atau dicari berdasarkan bulan dan tahun pencarian, laporan ini juga dapat diakses secara keseluruhan untuk setiap tahunnya.

\section{Desain}

Desain pada sistem informasi akuntansi penerimaan dan pengeluaran kas digambarkan dalam bentuk Use Case Diagram, Struktur Navigasi, dan Entity Relationship Diagram (ERD).

\section{Use Case Diagram}

Use Case Diagram pada Gambar 1 berikut ini merupakan pemodelan yang menggambarkan interaksi antara actor dan sistem yang dirancang. Sistem informasi akuntansi penerimaan dan pengeluaran kas dirancang berbasis web dengan 2 level pengguna, yaitu Bagian Keuangan dan Direktur. Ruang lingkup sistem digambarkan dalam use case diagram berikut ini.

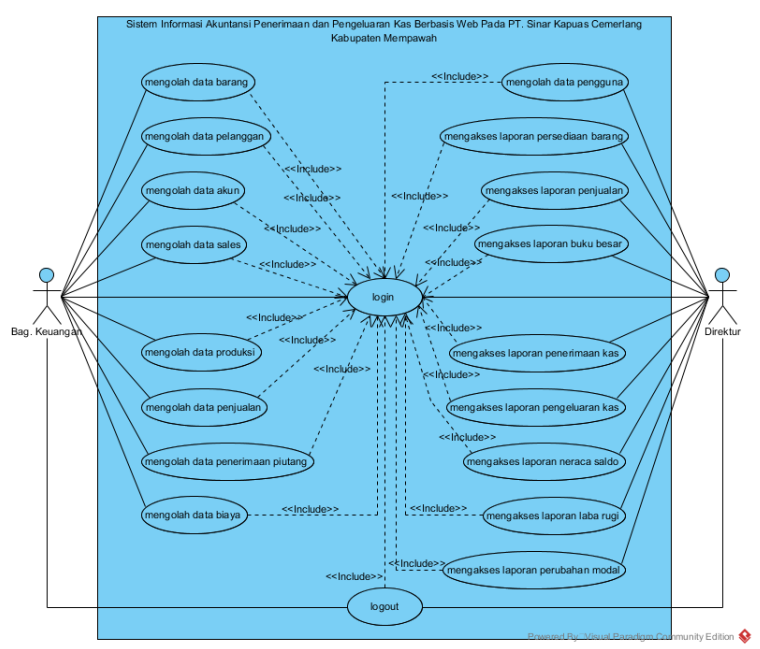

Gambar 1. Use Case Diagram Sistem Informasi Akuntansi Penerimaan dan Pengeluaran Kas 
Berdasarkan Gambar 1 diatas, Tabel 1 berikut ini merupakan deskripsi Use Case Diagram.

Tabel 1. Deskripsi Use Case Diagram Sistem Informasi Akuntansi Penerimaan dan Pengeluaran Kas

Use Case Narative Sistem Penerimaan dan Pengeluaran Kas
Tujuan Bagian Keuangan dan Direktur dapat mengelola dan mengakses data yang ada di dalam sistem informasi akuntansi penerimaan dan pengeluaran kas.

Deskripsi Aplikasi ini memberikan fasilitas kepada bagian keuangan untuk mengolah data barang, data pelanggan, data akun, data sales, data produksi, data penjualan, data penerimaan piutang, data biaya. Aplikasi ini juga memberikan fasilitas kepada direktur untuk mengolah data pengguna, mengakses laporan persediaan barang, laporan penjualan, laporan buku besar, laporan penerimaan kas, laporan pengeluaran kas, laporan neraca saldo, laporan laba rugi dan laporan perubahan modal.

\begin{tabular}{|c|c|c|}
\hline \multicolumn{3}{|c|}{ Skenario Utama } \\
\hline \multirow{2}{*}{\multicolumn{2}{|c|}{$\begin{array}{l}\text { Aktor } \\
\text { Kondisi Awal }\end{array}$}} & \multirow{2}{*}{$\begin{array}{l}\text { Bagian Keuangan dan Direktur } \\
\text { Bagian Keuangan \& Direktur harus } \\
\text { melakukan login dengan cara } \\
\text { mengisi username dan password. }\end{array}$} \\
\hline & & \\
\hline \multicolumn{2}{|r|}{ Aksi Aktor } & Reaksi Sistem \\
\hline 1. & $\begin{array}{l}\text { Bagian Keuangan } \\
\text { memilih menu data } \\
\text { barang }\end{array}$ & $\begin{array}{l}\text { Aplikasi menampilkan halaman } \\
\text { data barang. }\end{array}$ \\
\hline 2. & $\begin{array}{l}\text { Bagian Keuangan } \\
\text { memilih menu data } \\
\text { pelanggan }\end{array}$ & $\begin{array}{l}\text { Aplikasi menampilkan } \\
\text { data pelanggan. }\end{array}$ \\
\hline 3. & $\begin{array}{l}\text { Bagian Keuangan } \\
\text { memilih menu data } \\
\text { akun }\end{array}$ & $\begin{array}{l}\text { Aplikasi menampilkan halaman } \\
\text { data akun. }\end{array}$ \\
\hline 4. & $\begin{array}{l}\text { Bagian Keuangan } \\
\text { memilih menu sales }\end{array}$ & $\begin{array}{l}\text { Aplikasi menampilkan halaman } \\
\text { data sales. }\end{array}$ \\
\hline 5. & $\begin{array}{lr}\text { Bagian } & \text { Keuangan } \\
\text { memilih } & \text { menu } \\
\text { produksi } & \end{array}$ & $\begin{array}{l}\text { Aplikasi menampilkan halaman } \\
\text { data produksi. }\end{array}$ \\
\hline 6. & $\begin{array}{lr}\text { Bagian } & \text { Keuangan } \\
\text { memilih } & \text { menu } \\
\text { penjualan } & \end{array}$ & $\begin{array}{l}\text { Aplikasi menampilkan } \\
\text { data penjualan. }\end{array}$ \\
\hline 7. & $\begin{array}{lr}\text { Bagian } & \text { Keuangan } \\
\text { memilih } & \text { menu } \\
\text { penerimaan piutang }\end{array}$ & $\begin{array}{l}\text { Aplikasi menampilkan halaman } \\
\text { data penerimaan piutang. }\end{array}$ \\
\hline 8. & $\begin{array}{l}\text { Bagian Keuangan } \\
\text { memilih menu biaya }\end{array}$ & $\begin{array}{l}\text { Aplikasi menampilkan } \\
\text { data biaya. }\end{array}$ \\
\hline 9. & $\begin{array}{lr}\text { Direktur } & \text { memilih } \\
\text { menu } & \text { data } \\
\text { pengguna } & \end{array}$ & $\begin{array}{l}\text { Aplikasi menampilkan halaman } \\
\text { data pengguna. }\end{array}$ \\
\hline 10. & $\begin{array}{l}\text { Direktur memilih } \\
\text { menu laporan } \\
\text { persediaan barang }\end{array}$ & $\begin{array}{l}\text { Aplikasi menampilkan halaman } \\
\text { laporan persediaan barang. }\end{array}$ \\
\hline 11. & $\begin{array}{ll}\text { Direktur } & \text { memilih } \\
\text { menu } & \text { laporan } \\
\text { penjualan } & \end{array}$ & $\begin{array}{l}\text { Aplikasi menampilkan } \\
\text { laporan penjualan. }\end{array}$ \\
\hline 12. & $\begin{array}{l}\text { Direktur memilih } \\
\text { menu laporan buku } \\
\text { besar }\end{array}$ & $\begin{array}{l}\text { Aplikasi menampilkan } \\
\text { laporan buku besar. }\end{array}$ \\
\hline 13. & Direktur & menampilkan \\
\hline
\end{tabular}

menu laporan laporan penerimaan kas.

penerimaan kas

14. Direktur memilih Aplikasi menampilkan halaman menu laporan laporan pengeluaran kas. pengeluaran kas

15. Direktur memilih Aplikasi menampilkan halaman menu laporan laporan neraca saldo.

neraca saldo

16. Direktur memilih Aplikasi menampilkan halaman menu laporan laba laporan laba rugi. rugi

17. Direktur memilih Aplikasi menampilkan halaman menu laporan laporan perubahan modal. perubahan modal

\begin{tabular}{ll} 
Kondisi Akhir & $\begin{array}{l}\text { Jika sesuai perintah maka aplikasi } \\
\text { akan menampilkan menu yang } \\
\text { dipilih oleh pengguna }\end{array}$ \\
\hline
\end{tabular}

\section{Rancangan Basis Data}

Rancangan basis data pada sistem informasi akuntansi penerimaan dan pengeluaran kas pada PT. Sinar Kapuas Cemerlang digambarkan dalam bentuk Entity Relationship Diagram (ERD) berikut ini.

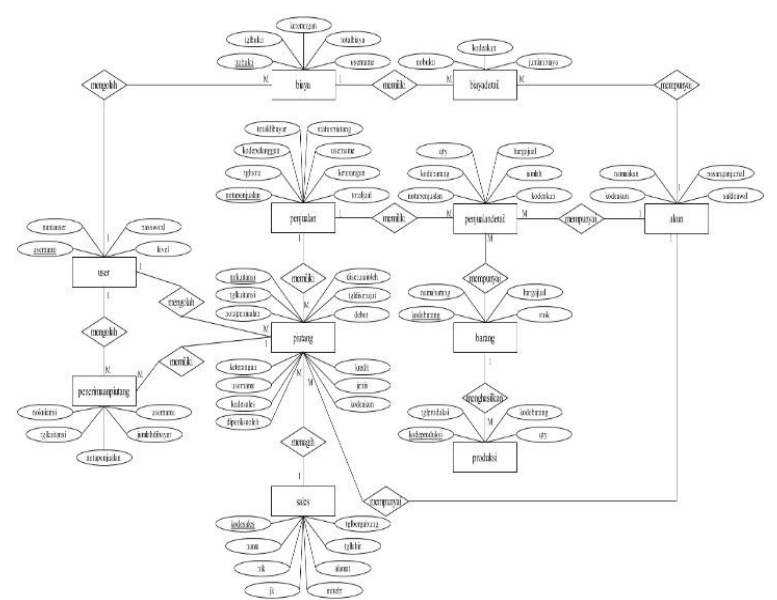

Gambar 2. Entity Relationship Diagram Sistem Informasi Akuntansi Penerimaan dan Pengeluaran Kas

\section{Struktur Navigasi}

Struktur navigasi merupakan halaman web atau dokumen web yang mempunyai struktur yang jelas serta tersusun dengan teratur. Rancangan struktur navigasi pada web digunakan untuk mengkaitkan halaman web dengan halaman web yang saling keterhubungan satu sama lain dengan hypertext. Struktur navigasi website bukan menggambarkan keterhubungan antar menumenu, melainkan dokumen website tersebut (Frieyadie, 2019)

Model struktur navigasi yang digunakan adalah struktur hierarchy, yang menjelaskan hubungan antara dua atau lebih peringkat (Frieyadie \& Fatayat, 2019).

Bagian Keuangan dan Direktur memiliki level akses yang berbeda. Arah penggunaan sistem 
dari masing-masing level digambarkan pada struktur navigasi sebagai berikut.

1. Struktur Navigasi Bagian Keuangan

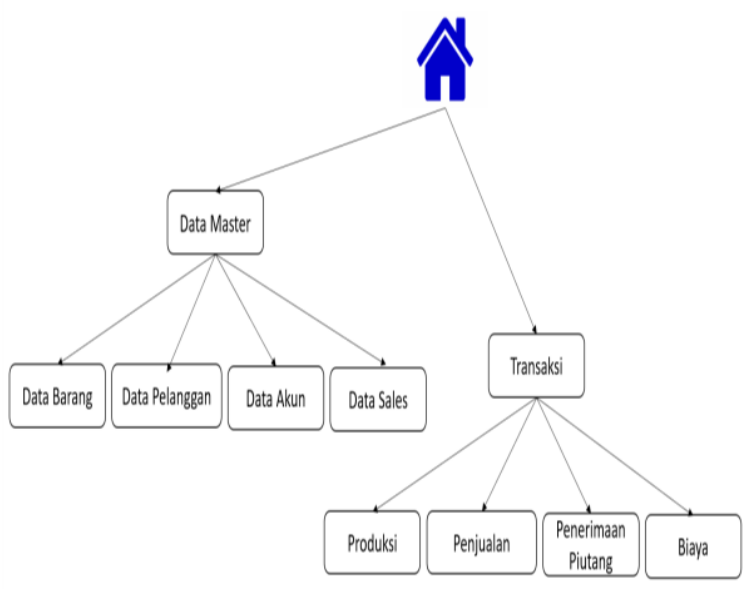

Gambar 3. Struktur Navigasi Bagian Keuangan

2. Struktur Navigasi Direktur

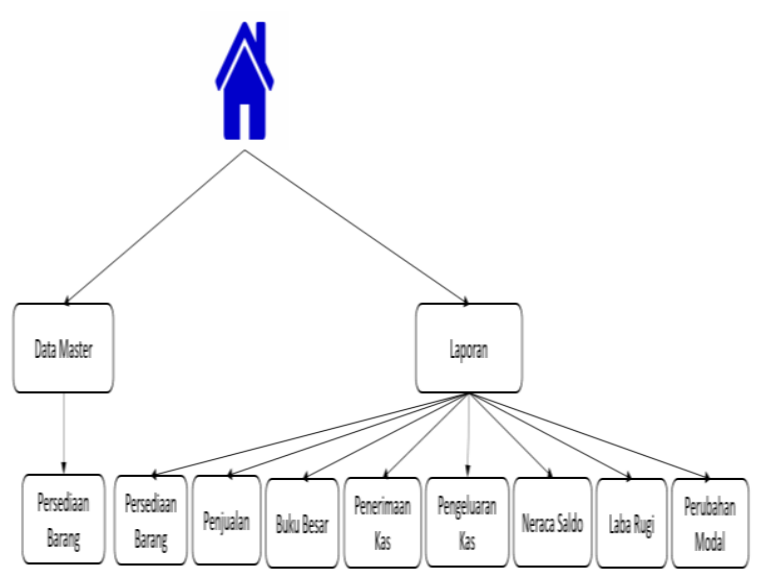

Gambar 4. Struktur Navigasi Direktur

Tampilan antar muka atau user interface dari sistem informasi akuntansi penerimaan dan pengeluaran kas pada PT. Sinar Kapuas Cemerlang akan disajikan sesuai dengan level akses penggunanya, yaitu Bagian Keuangan dan Direktur. Untuk masuk ke halaman utama, masingmasing level harus berhasil melakukan login.

\section{A. Bagian Bagian Keuangan}

Fasilitas yang didapat oleh Bagian Keuangan dari sistem informasi akuntansi penerimaan dan pengeluaran kas pada PT. Sinar Kapuas Cemerlang ini terdiri dari mengolah data barang, data pelanggan, data akun, data sales, data produksi, data penjualan, data penerimaan piutang dan data biaya. Berikut ini adalah hasil tampilan antar muka atau user interface yang disediakan untuk level pengguna Bagian Keuangan.

\section{Tampilan Menu Data Barang}

Pada halaman ini, Bagian Keuangan dapat mengelola data barang mulai dari penambahan, pengubahan dan penghapusan data barang.

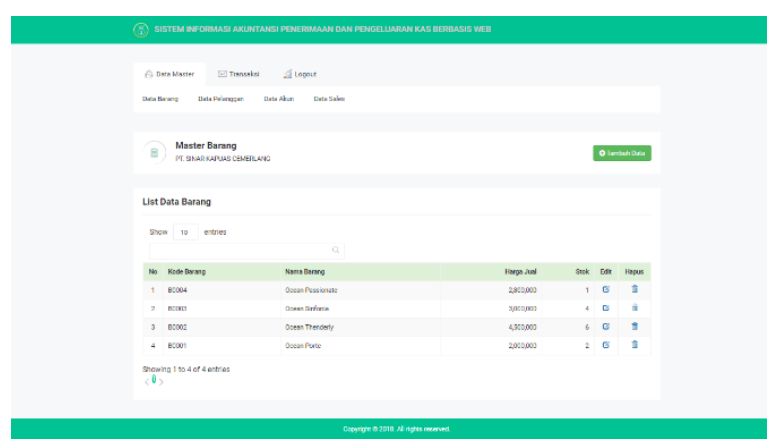

Gambar 5. Tampilan Menu Data Barang

\section{Tampilan Menu Data Pelanggan}

Pada halaman ini, Bagian Keuangan dapat mengelola data pelanggan mulai dari penambahan, pengubahan dan penghapusan data pelanggan.

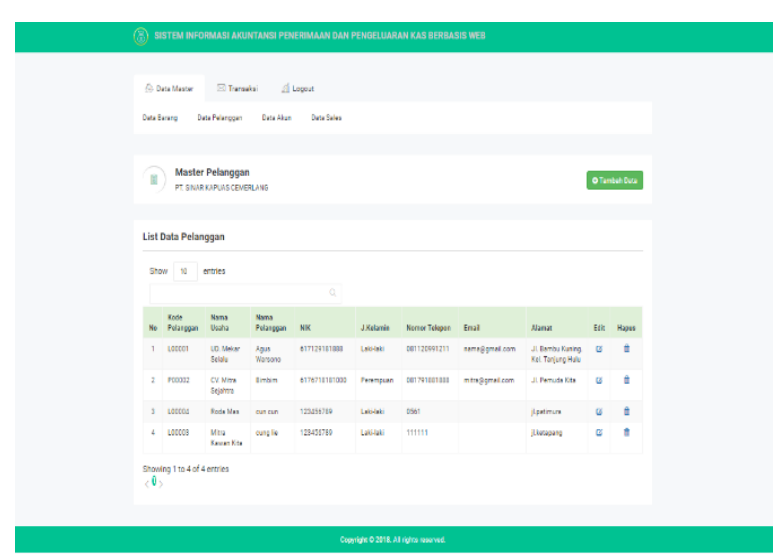

Gambar 6. Tampilan Menu Data Pelanggan

3. Tampilan Menu Data Akun

Pada halaman ini, Bagian Keuangan dapat mengelola data akun mulai dari penambahan, pengubahan dan penghapusan data akun.

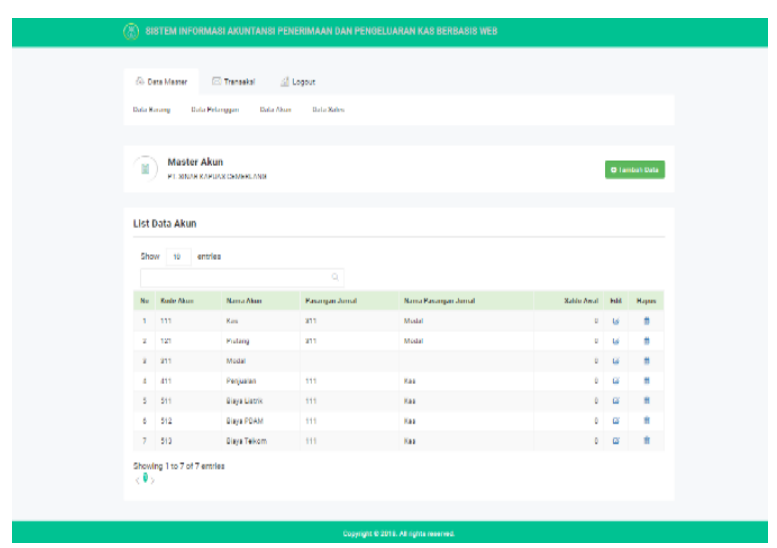

Gambar 7. Tampilan Menu Data Akun 
4. Tampilan Menu Data Sales

Pada halaman ini, Bagian Keuangan dapat mengelola data sales mulai dari penambahan, pengubahan dan penghapusan data sales.

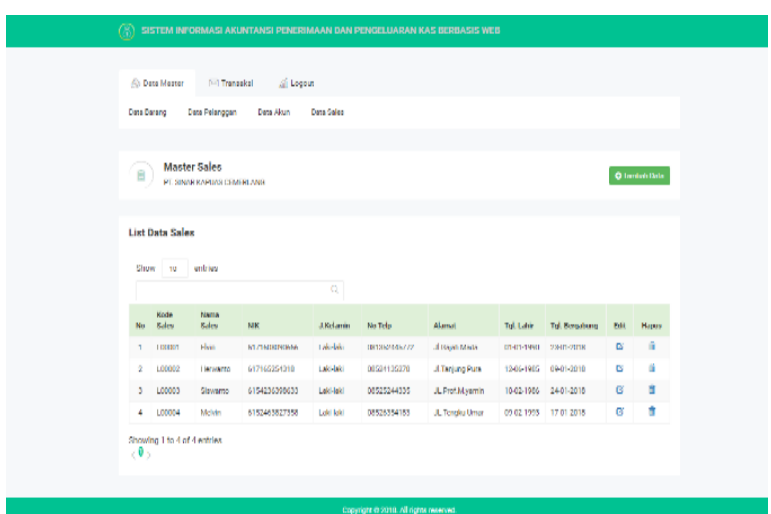

Gambar 8. Tampilan Menu Data Sales

5. Tampilan Menu Data Produksi

Pada halaman ini, Bagian Keuangan dapat mengelola data produksi mulai dari penambahan, pengubahan dan penghapusan data produksi.

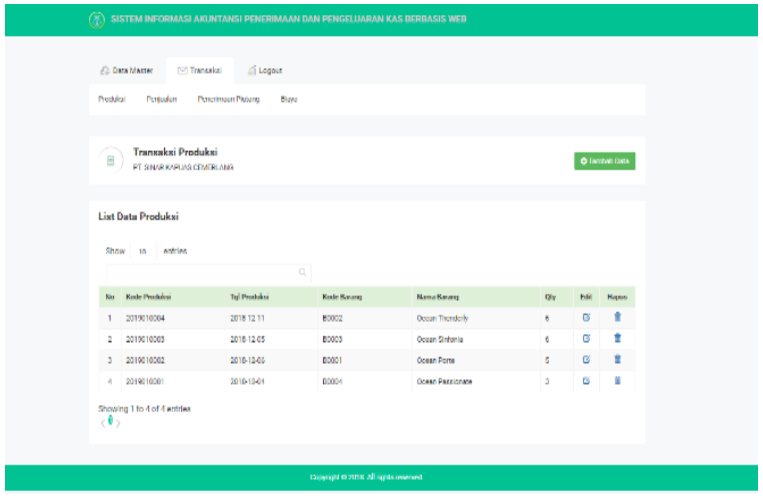

Gambar 9. Tampilan Menu Data Produksi

6. Tampilan Menu Data Penjualan

Pada halaman ini, Bagian Keuangan dapat mengelola data penjualan mulai dari penambahan, pengubahan dan penghapusan data penjualan.

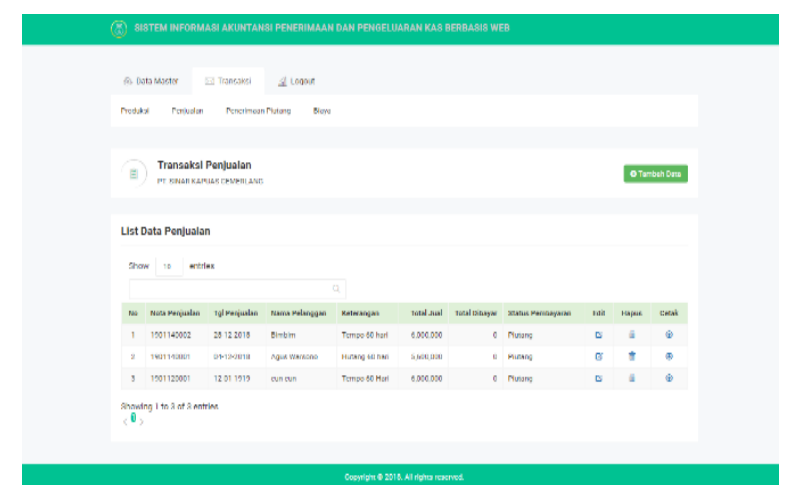

Gambar 10. Tampilan Menu Data Penjualan

\section{Tampilan Menu Data Penerimaan Piutang}

Pada halaman ini, Bagian Keuangan dapat mengelola data penerimaan piutang mulai dari penambahan, pengubahan dan penghapusan data penerimaan piutang.

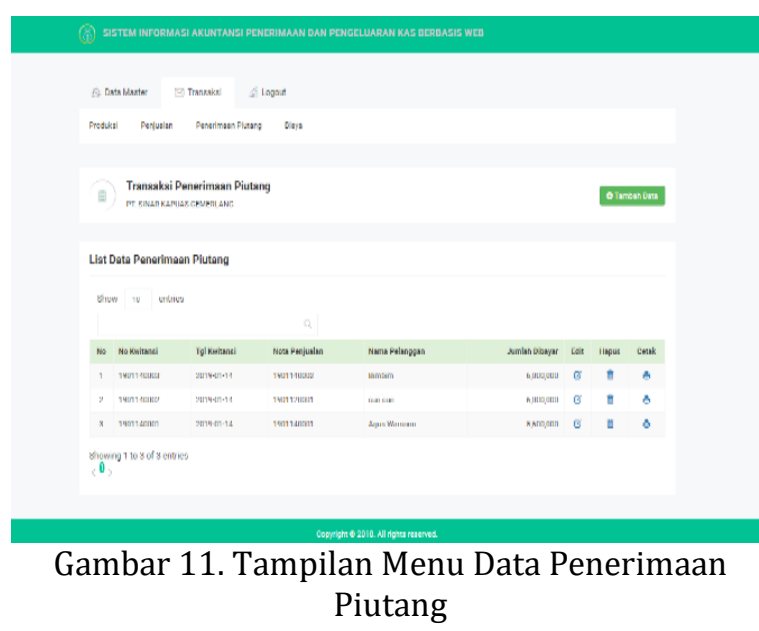

8. Tampilan Menu Data Biaya

Pada halaman ini, Bagian Keuangan dapat mengelola data biaya mulai dari penambahan, pengubahan dan penghapusan data biaya.

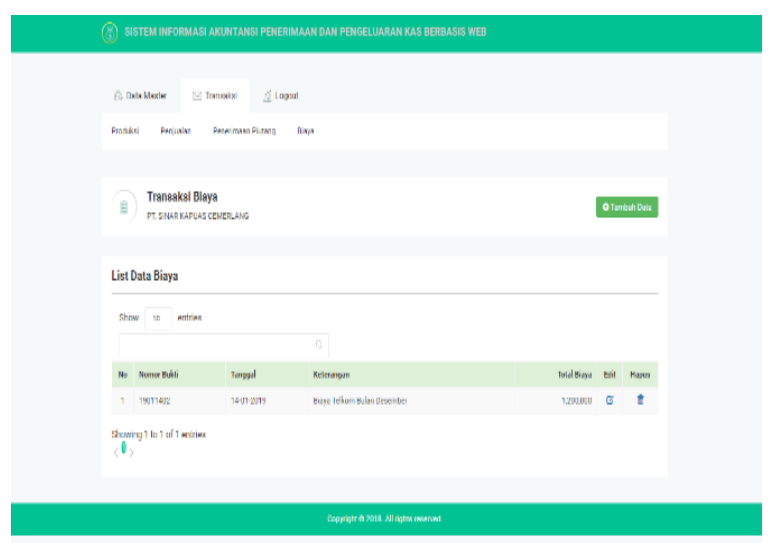

Gambar 12. User Interface Menu Data Biaya

\section{B. Bagian Direktur}

Fasilitas yang didapat oleh Direktur dari sistem informasi akuntansi penerimaan dan pengeluaran kas pada PT. Sinar Kapuas Cemerlang ini terdiri dari mengolah data pengguna, mengakses laporan persediaan barang, laporan penjualan, laporan buku besar, laporan penerimaan kas, laporan pengeluaran kas, laporan neraca saldo, laporan laba rugi dan laporan perubahan modal. Berikut ini adalah hasil tampilan antar muka atau user interface yang disediakan untuk level pengguna Direktur. 
1. Tampilan Menu Data Pengguna

Pada halaman ini, Direktur dapat mengelola data pengguna mulai dari penambahan, pengubahan dan penghapusan data pengguna.

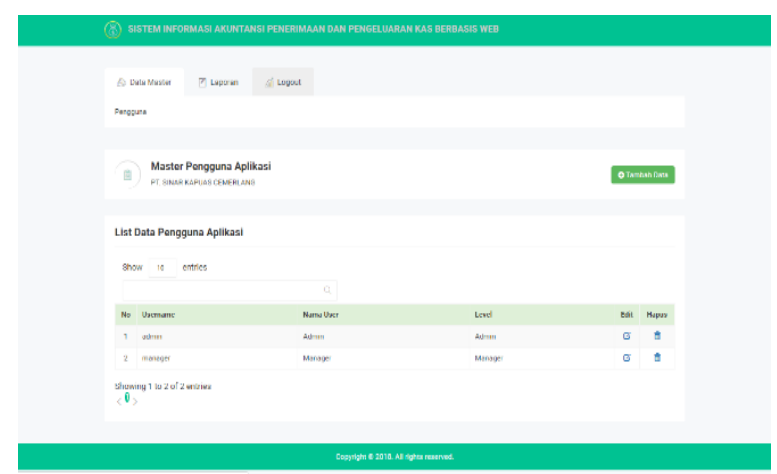

Gambar 13. Tampilan Menu Data Pengguna

2. Tampilan Menu Laporan Persediaan Barang

Pada halaman laporan persediaan barang, Direktur dapat melihat atau mengakses laporan persediaan barang sesuai dengan periode pencarian.

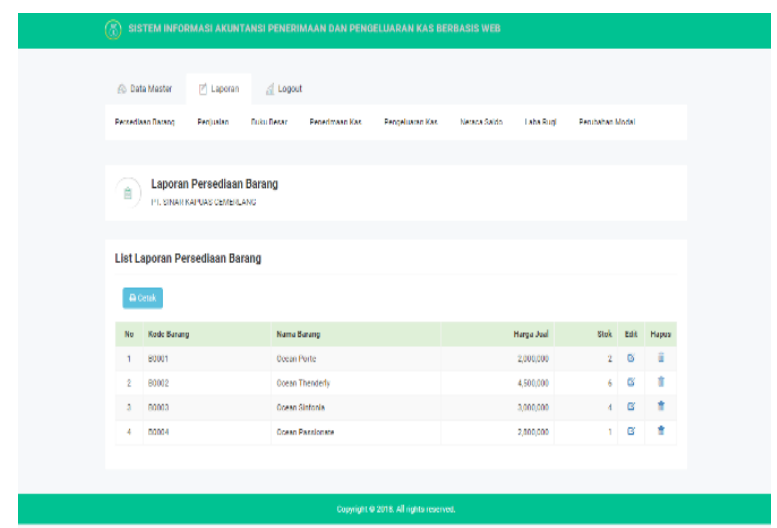

Gambar 14. Tampilan Menu Laporan Persediaan Barang

3. Tampilan Menu Laporan Penjualan

Pada halaman laporan penjualan, Direktur dapat melihat atau mengakses laporan penjualan sesuai dengan periode pencarian.

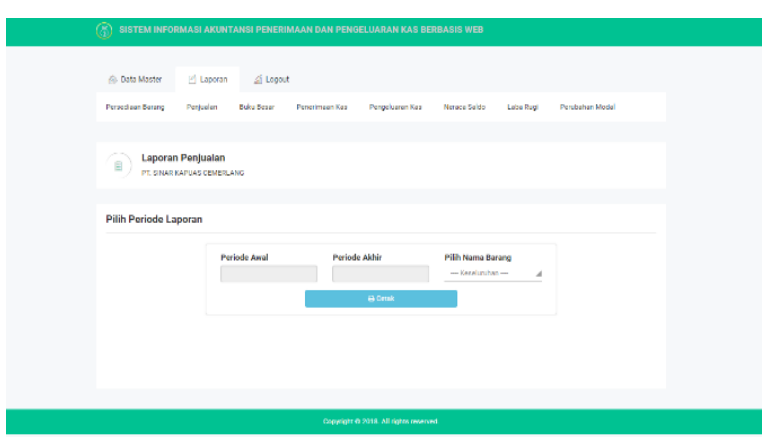

Gambar 15. Tampilan Menu Laporan Penjualan

\section{Tampilan Menu Laporan Buku Besar}

Pada halaman laporan buku besar, Direktur dapat melihat atau mengakses laporan buku besar sesuai dengan periode pencarian.

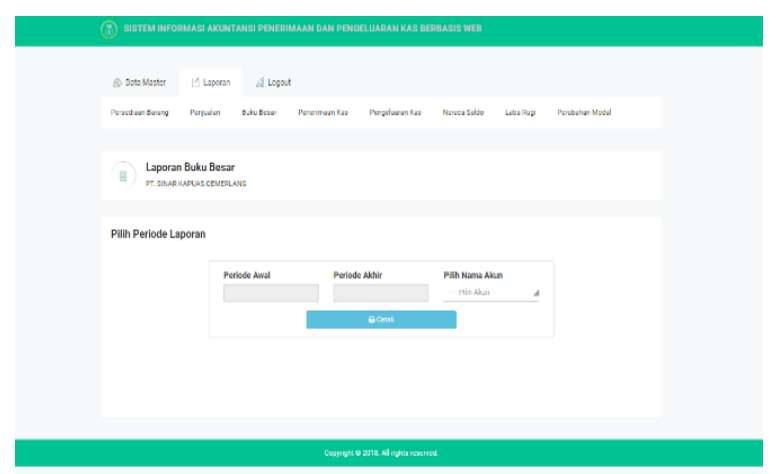

Gambar 16. Tampilan Menu Laporan Buku Besar

5. Tampilan Menu Laporan Penerimaan Kas Pada halaman penerimaan kas, Direktur dapat melihat atau mengakses laporan penerimaan kas sesuai dengan periode pencarian.

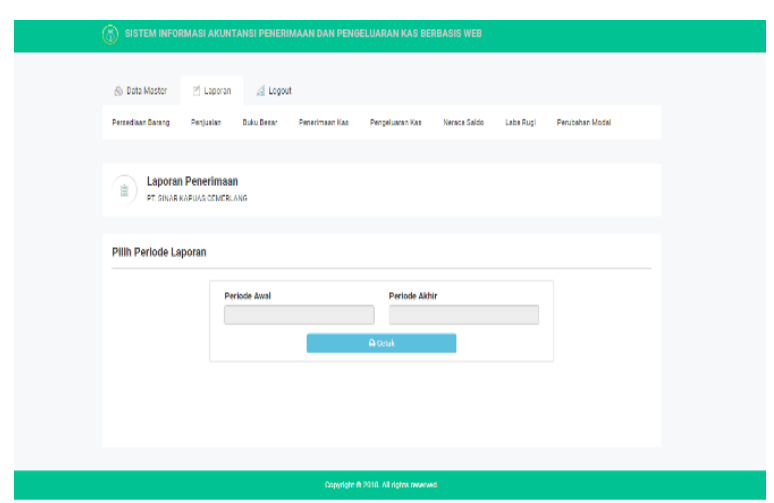

Gambar 17. Tampilan Menu Laporan Penerimaan Kas

6. Tampilan Menu Laporan Pengeluaran Kas Pada halaman laporan pengeluaran kas, Direktur dapat melihat atau mengakses laporan pengeluaran kas sesuai dengan periode pencarian.

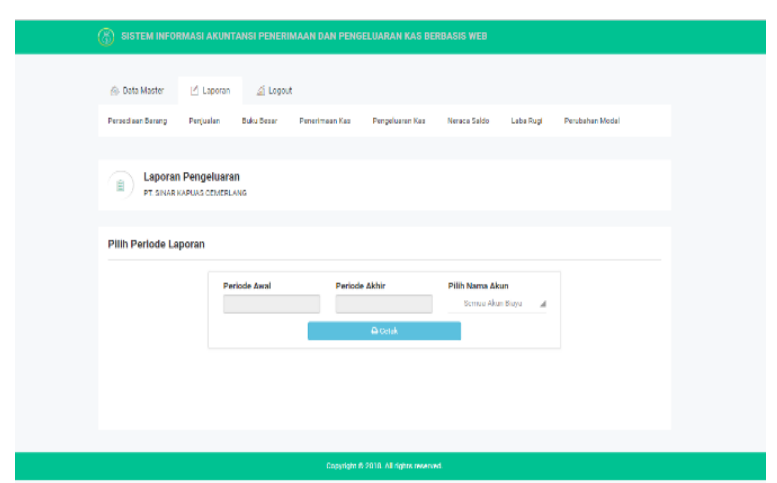

Gambar 18. Tampilan Menu Laporan Pengeluaran Kas 


\section{Tampilan Menu Laporan Neraca Saldo}

Pada halaman laporan neraca saldo Direktur dapat melihat atau mengakses laporan neraca saldo sesuai dengan periode pencarian.

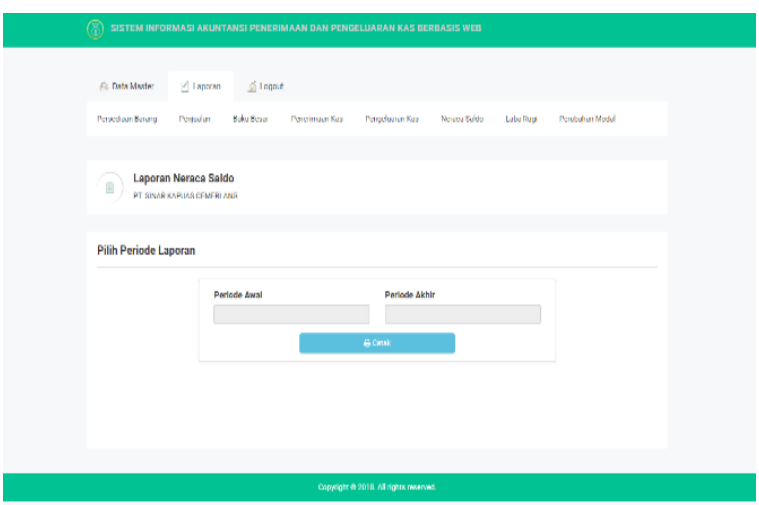

Gambar 19. Tampilan Menu Laporan Neraca Saldo

8. Tampilan Menu Laporan Neraca Laba Rugi Pada halaman laporan laba rugi, Direktur dapat melihat atau mengakses laporan laba rugi sesuai dengan periode pencarian.

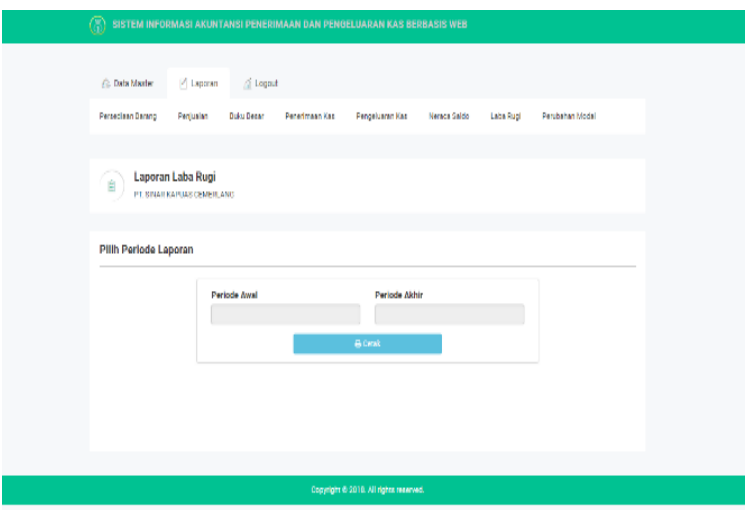

Gambar 20. Tampilan Menu Laporan Laba Rugi

9. Tampilan Menu Laporan Perubahan Modal Pada halaman laporan perubahan modal, Direktur dapat melihat atau mengakses laporan perubahan modal sesuai dengan periode pencarian.

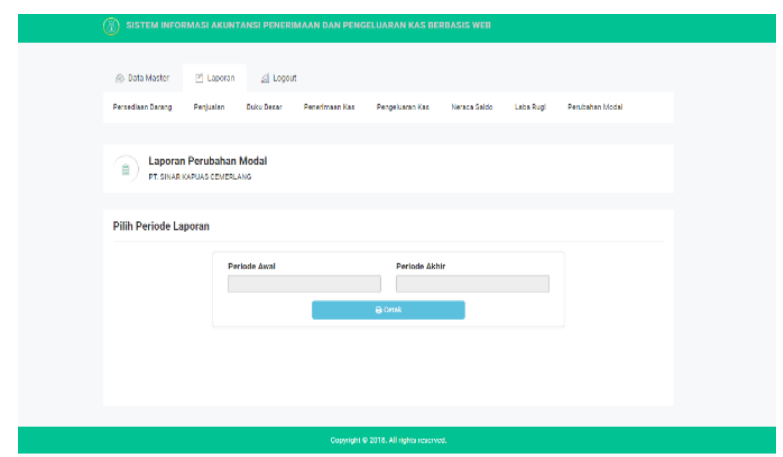

Gambar 21. Tampilan Menu Laporan Perubahan Modal

\section{Pembuatan Kode Program}

Perangkat lunak (software) yang diperlukan pembuatan sistem informasi akuntansi penerimaan dan pengeluaran kas pada PT. Sinar Kapuas Cemerlang, yaitu:

1. Beberapa komponen diantaranya:
a. Apache server versi 2.4.3.
b. MySQL versi 5.1.36
c. PHP versi 5.3.0

2. Bahasa pemograman yang digunakan yaitu: PHP, HTML, CSS, javascript, jQuery dan Bootstraps yang diolah dengan sublime text 3 sebagai web editor.

3. Web browser seperti google chrome dan mozilla firefox.

\section{Pengujian}

Pengujian dilakukan untuk menguji kelayakan fungsional dari sistem informasi akuntansi penerimaan dan pengeluaran kas pada PT. Sinar Kapuas Cemerlang. Teknik yang digunakan untuk pengujian ini adalah menggunakan tekniks black box testing. Pengujian yang dilakukan hanya mengamati hasil eksekusi dan memeriksa kelayakan fungsional dari sistem informasi akuntansi penerimaan dan pengeluaran kas pada PT. Sinar Kapuas Cemerlang yang telah dibuat.

1. Pengujian browser

Tabel 2. Black Box Testing Browser

\begin{tabular}{lll}
\hline 1. & Skenario Pengujian & Buka dengan Google Chrome \\
\cline { 2 - 3 } & Test Case & Google Chrome (terbuka) \\
\hline Hasil yang Diharapkan & $\begin{array}{l}\text { Aplikasi dapat diakses dan } \\
\text { tampilan sesuai }\end{array}$ \\
\hline Hasil Pengujian & Sesuai harapan \\
\hline Kesimpulan & Valid \\
\hline Skenario Pengujian & Buka dengan Mozila Firefox \\
\hline Test Case & Mozila Firefox (terbuka) & \\
\hline Hasil yang Diharapkan & $\begin{array}{l}\text { Aplikasi dapat diakses dan } \\
\text { tampilan sesuai }\end{array}$ \\
\hline Hasil Pengujian & Sesuai harapan \\
\hline Kesimpulan & Valid & \\
\hline
\end{tabular}

\section{Pengujian login}

Tabel 3. Black Box Testing Halaman Login

\begin{tabular}{|c|c|c|}
\hline \multirow[t]{5}{*}{1.} & Skenario Pengujian & $\begin{array}{lrrr}\text { Jika } & \text { salah } & \text { satu } & \text { kolom } \\
\text { dikosongkan } & & \\
\end{array}$ \\
\hline & Test Case & username: (kosong) \\
\hline & Hasil yang Diharapkan & $\begin{array}{l}\text { Aplikasi menolak akses dan } \\
\text { menampilkan pesan "username } \\
\text { atau password anda salah, } \\
\text { silahkan coba lagi" }\end{array}$ \\
\hline & Hasil Pengujian & Sesuai harapan \\
\hline & Kesimpulan & Valid \\
\hline \multirow[t]{2}{*}{2.} & Skenario Pengujian & $\begin{array}{l}\text { Kolom terisi namun tidak } \\
\text { sesuai (username, password } \\
\text { dan level akses tidak sesuai) }\end{array}$ \\
\hline & Test Case & $\begin{array}{l}\text { username: }(111111) \\
\text { password: }(111111)\end{array}$ \\
\hline
\end{tabular}




\begin{tabular}{lll}
\hline Hasil yang Diharapkan & $\begin{array}{l}\text { Aplikasi menolak akses dan } \\
\text { menampilkan pesan “username } \\
\text { atau password anda salah, } \\
\text { silahkan cobalagi" }\end{array}$ \\
\hline Hasil Pengujian & Sesuai harapan \\
\hline Kesimpulan & Valid \\
\hline 3. & Skenario Pengujian & $\begin{array}{l}\text { Kolom terisi dan sesuai } \\
\text { (username dan password } \\
\text { sesuai) }\end{array}$ \\
\hline Test Case & $\begin{array}{l}\text { username: (admin) } \\
\text { password: (admin) }\end{array}$ \\
\hline Hasil yang Diharapkan & $\begin{array}{l}\text { Aplikasi menerima akses dan } \\
\text { mengantarkan pengguna ke } \\
\text { halaman dashboard. }\end{array}$ \\
\hline Hasil Pengujian & Sesuai harapan \\
\hline Kesimpulan & Valid \\
\hline
\end{tabular}

\section{Simpulan}

\section{SIMPULAN DAN SARAN}

Berdasarkan hasil pembahasan yang telah diuraikan, maka dapat disimpulkan bahwa sistem informasi akuntansi penerimaan dan pengeluaran kas yang dibuat ini menyediakan pengolahan penerimaan dan pengeluaran kas yang dilengkapi dengan laporan keuangan. Level akses pada aplikasi ini terdiri dari bagian keuangan dan direktur. Bagian keuangan pengolahan data barang, data pelanggan, data akun, data sales, data produksi, data penjualan, data penerimaan piutang dan data biaya. Direktur mengolah data pengguna, mengakses laporan persediaan barang, laporan penjualan, laporan buku besar, laporan penerimaan kas, laporan pengeluaran kas, laporan neraca saldo, laporan laba rugi dan laporan perubahan modal. Dengan kata lain, sistem informasi akuntansi penerimaan dan pengeluaran kas pada PT. Sinar Kapuas Cemerlang Kabupaten Mempawah menyediakan pengolahan data dan transaksi dengan sesuai dengan aturan akuntansi.

\section{Saran}

Saran yang dapat dijadikan sebagai bahan masukan dan pertimbangan untuk sistem informasi akuntansi penerimaan dan pengeluaran kas pada PT. Sinar Kapuas Cemerlang Kabupaten Mempawah berikutnya adalah penambahan fungsi seperti pengadaan bahan baku untuk pembuatan spring bed.

\section{DAFTAR REFERENSI}

Amin, R. (2017). Rancang Bangun Sistem Informasi Penerimaan Siswa Baru Pada SMK Budhi Warman 1 Jakarta. JITK (Jurnal Ilmu Pengetahuan Dan Teknologi Komputer), 2(2), 113-121. Retrieved from http://ejournal.nusamandiri.ac.id/index.php /jitk/article/view/391
Arizona, N. D. (2017). PERANCANGAN SISTEM INFORMASI PENJUALAN DAN PEMBELIAN OBAT PADA APOTEK ZAIRA. In Konferensi Nasional Ilmu Sosial \& Teknologi (KNiST) 2017 (pp. 674-678). Jakarta: LPPM BSI.

Damayanti, \& Hernandez, M. Y. (2018). Sistem informasi akuntansi penerimaan dan pengeluaran kas pada kpri andan jejama kabupaten pesawaran, 12(2), 57-61.

Firmansyah, Y., \& Udi, U. (2017). Penerapan Metode SDLC Waterfall Dalam Pembuatan Sistem Informasi Akademik Berbasis Web Studi Kasus Pondok Pesantren Al-Habib Sholeh Kabupaten Kubu Raya, Kalimantan Barat. Jurnal Teknologi Dan Manajemen Informatika, $4(1)$. https://doi.org/10.26905/jtmi.v4i1.1605

Frieyadie, F. (2015). PEMBANGUNAN SISTEM INFORMASI INVENTORY MENGGUNAKAN LINEAR SEQUENTIAL MODEL UNTUK PENINGKATAN LAYANAN INVENTORY BARANG. Jurnal Techno Nusa Mandiri, 12(2), 209-114.

https://doi.org/10.33480/TECHNO.V12I2.45 1

Frieyadie, F. (2019). Struktur Navigasi Pada Website. Retrieved from http://frieyadie.web.id/struktur-navigasipada-website/

Frieyadie, \& Fatayat, U. (2019). PENGGUNAAN MODEL WATERFALL DALAM PERANCANGAN APLIKASI PENJUALAN KOSMETIK BERBASIS WEB, 1(4).

Hak, A. N., Slamet, C., \& Kurniawati, R. (2014). IMPLEMENTASI SISTEM INFORMASI KEUANGAN SISWA BERBASIS SMS GATEWAY DI SMK MUHAMMADIYAH 2 KADUNGORA. Jurnal Algoritma, 11(1). Retrieved from http://www.sttgarut.ac.id/jurnal/index.php/ algoritma/article/view/119

Primandani, V., \& Widodo, T. W. (2012). Purwarupa Sistem Pembayaran Retribusi Jalan Tol Berbasis Teknologi RFID. IJEIS (Indonesian Journal of Electronics and Instrumentation Systems), 2(1), 11-20. https://doi.org/10.22146/ijeis.2336

Riswan, \& Kesuma, Y. F. (2014). Analisis Laporan Keuangan sebagai dasar dalam Penilaian 
Kinerja Keuangan PT. Budi Satria Wahana Motor, 5(1). Retrieved from http://jurnal.ubl.ac.id/index.php/jak/article /view/449

Saifudin, \& Ardani, F. P. (2017). SISTEM INFORMASI AKUNTANSI PENERIMAAN DAN PENGELUARAN KAS DALAM MENINGKATKAN PENGENDALIAN INTERNAL ATAS PENDAPATAN PADA RSUP
Dr . KARIADI SEMARANG. Jurnal Riset Akuntansi Keuangan, 2(2).

Sholikhah, I., Sairan, M., \& Syamsiah, N. O. (2017). Aplikasi Pembelian Dan Penjualan Barang Dagang Pada Cv Gemilang Muliatama Cikarang. Jurnal Teknik Komputer, III(1), 1623. 